\title{
Implication of Placenta Praevia on Baby Delivery
}

\author{
Hao Hsuan Mark Tsai* \\ Monash University, Austrilia
}

Submission: March 26, 2017; Published: June 01, 2017

*Corresponding author: Hao Hsuan Mark Tsai, Monash University, Austrilia, Tel: +61-431-748-861; Email: marktsaihh@gmail.com

\section{Introduction}

With increasing maternal age in recent years, the incidence of placenta praevia will continue to increase in Australia [1]. Placenta praevia refers to complete or partial insertion of the placenta in the lower segment of the uterus. Apart from maternal age [2], other risk factors include maternal parity [3], multiple gestations [4,5], previous history of caesarean section [6] and smoking $[4,7]$. Clinical suspicion of placenta praevia should be ruled out in women who present with painless vaginal bleeding after 20 weeks of gestation. Ultrasound imaging provides a definitive diagnosis by visualization of the relationship between the placenta and the internal cervical os [8]. This case report highlights the implications of placenta praevia on the delivery of the baby.

\section{Case Report}

\section{History}

Susan is a 29 year-old primiparous woman (G3P0) who has been referred to the birth suite for delivery at $36+2$ weeks due to new abnormal Doppler findings on background of recent episode of decreased fetal movement. At 34+6 weeks gestation, Susan felt that there was a reduction in fetal movement despite normal fetal heart auscultation with Doppler and reassuring cardiotocography traces.

Susan had two early pregnancy losses at seven and eight weeks of gestation in the past. In this pregnancy, she has been diagnosed with gestational diabetes mellitus at 28 weeks which is under diet control and vitamin D deficiency $(67 \mathrm{nmol} / \mathrm{L})$ which is managed with multivitamin supplements. Susan is otherwise fit and well with no known drug allergies.

\section{Examination}

Susan appears well on general inspection. An examination finding reveals that the fetus is in cephalic presentation, longitudinal lie, ROT position with head palpable $4 / 5$ above pelvic brim. No vaginal examination has been performed due to suspected placenta praevia.

\section{Investigation}

Susan is blood group B+ with no red blood cell antibodies. Serology is negative for sexually transmitted diseases and immune to rubella. Her results of aneuploidy screening through the first trimester combined screening yields a low risk for chromosomal abnormalities of the fetus.

Ultrasound at 20+2 weeks demonstrates that the placenta is anterior on maternal right overlapping the internal os by $6 \mathrm{~cm}$ and no abnormalities in fetal morphology. Follow-up ultrasound at $31+6$ week shows the placenta to be $1.4 \mathrm{~cm}$ from the internal os with normal fetal biometry and biophysical profile. Subsequent ultrasound at $36+2$ weeks measured the middle cerebral artery pulsatility index to be below the 5 th centile reflecting a redistribution of cardiac output to the brain. The placenta remains $1.3 \mathrm{~cm}$ from the internal os.

\section{Management}

In light of recent Doppler findings and decreased fetal movement, suspected fetal compromise rendered the need for emergency caesarean section. A healthy baby of 2535g was delivered with an estimated blood loss of $400 \mathrm{~mL}$.

\section{Discussion}

Placenta praevia is a result of failure of low-lying placentas to migrate in the third trimester. Placental migration describes the apparent movement of the placenta from the internal os [9]. The placenta does not move per se but rather owing to the differential growth of the uterine segment and the placenta, there is a net change in position relative to the internal os. Placenta is more likely to grow towards the fundus with greater blood supply in the upper uterine segment while the stretching of uterine muscles fibres promotes the development of the lower uterine segment inferiorly during the third trimester.

Placenta praevia is associated with maternal haemorrhage, preterm delivery and preterm birth. Forty percent of women with placenta praevia may have preterm delivery as labour 
becomes unpredictable approaching term [10]. Timing of delivery plays an important role in maximising fetal growth and minimising the risk of antepartum haemorrhage. Royal College of Obstetricians and Gynaecologists recommends that all elective cases should be delayed until 38 weeks of gestation [8]. There are no observational or interventional studies to date to refute or support this expert opinion.

Mode of delivery may impact on subsequent pregnancies as the presence of a scar from caesarean section further predisposes women the risk of morbidly adherent placenta (placenta accrete, increta, precreta) especially if the placenta is anterior. Placenta praevia alone should not preclude women from aiming for vaginal delivery. Major placenta praevia, where the placenta covers the internal os, is invariably an absolute indication for caesarean section. However, if the placenta edge approaches but not covering the internal os in minor placenta praevia, the indication for caesarean section is less apparent.

A retrospective cohort study $(n=127)$ suggests $2 \mathrm{~cm}$ as the threshold limit for vaginal delivery [11]. There was a statistically significant difference $(\mathrm{p}=0.0004)$ in the mean distance between the placental edge and the internal cervical os for those delivered by caesarean section than those delivered by vaginal birth. Another retrospective cohort study $(n=121)$ found two of 40 and 22 of 39 women achieved vaginal delivery with placentas within $0.1-2.0 \mathrm{~cm}$ and $>2.0 \mathrm{~cm}$ of the internal os respectively [12]. Both studies are at high risk of performance and detection bias as blinding of ultrasound findings is not possible. Consultant obstetricians cannot make decisions as to mode of delivery without knowledge of the ultrasound report while women may simply elect for a caesarean section rather than failing attempt at vaginal delivery. Further research is warranted to quantify the criteria as to when vaginal delivery can be considered for women with placenta praevia through a randomised controlled trial.

At present, there is paucity of evidence available as to the timing and mode of delivery for women with placenta praevia. Management of pregnancies complicated by placenta praevia involves an interplay of fetal maturity, maternal haemorrhage and onset of labour. Whilst individual clinical circumstances may trigger an earlier delivery, it is recommended that delivery should be deferred until 38 weeks of gestation. Decision as to whether it is delivered abdominally or vaginally should take into account of clinical and ultrasound findings as well as any personal preferences the woman may have.

\section{Conclusion}

It is important to confirm the placenta location on the 20 weeks gestation ultrasound to determine the need for follow-up ultrasound for low-lying placentas so an appropriate mode of delivery can be arranged in a timely manner.

\section{References}

1. (2015) Births, Australia. Australian Bureau of Statistics.

2. Biro M, Davey M, Carolan M, Kealy M (2012) Advanced maternal age and obstetric morbidity for women giving birth in Victoria, Australia: A population-based study. Aust N Z J Obstet Gynaecol 52(3): 229-234.

3. Babinszki A, Kerenyi T, Torok O, Grazi V, Lapinski RH, et al. (1999) Perinatal outcome in grand and great-grand multiparity: Effects of parity on obstetric risk factors. Am J Obstet Gynecol 181(3): 669-674.

4. Ananth C, Demissie K, Smulian J, Vintzileos A (2003) Placenta previa in singleton and twin births in the United States, 1989 through 1998: A comparison of risk factor profiles and associated conditions. Am J Obstet Gynecol 188(1): 275-281.

5. Weis M, Harper L, Roehl K, Odibo A, Cahill A (2012) Natural History of Placenta Previa in Twins. Obstet Gynecol 120(4): 753-758.

6. Silver R, Landon M, Rouse D, Leveno K, Spong C, et al. (2006) Maternal Morbidity Associated With Multiple Repeat Cesarean Deliveries. Obstet Gynecol 107(6): 1226-1232.

7. Usta I, Hobeika E, Musa A, Gabriel G, Nassar A (2004) Placenta previaaccreta: Risk factors and complications. Am J Obstet Gynecol 193(3 Pt 2): $1045-1049$.

8. (2011) Green-top Guideline No. 27 Placenta Praevia, Placenta Praevia Accreta and Vasa Praevia: Diagnosis and Management.

9. King D (1973) Placental Migration Demonstrated by Ultrasonography. Radiology 109(1): 167-170.

10. Zlatnik MG, Cheng YW, Norton ME, Thiet MP, Caughey AB (2007) Placenta previa and the risk of preterm delivery. J Matern Fetal Neonatal Med 20(10): 719-723.

11. Oppenheimer LW, Farine D, Ritchie JW, Lewinsky RM, Telford J, et al. (1991) What is a low-lying placenta? Am J Obstet Gynecol 165(4 Pt 1): 1036-1038.

12. Bhide A, Prefumo F, Moore J, Hollis B, Thilaganathan B (2003) Placental edge to internal os distance in the late third trimester and mode of delivery in placenta praevia. BJOG 110(9): 860-864.

Your next submission with Juniper Publishers will reach you the below assets

- Quality Editorial service

- Swift Peer Review

- Reprints availability

- E-prints Service

- Manuscript Podcast for convenient understanding

- Global attainment for your research

- Manuscript accessibility in different formats

( Pdf, E-pub, Full Text, Audio)

- Unceasing customer service

Track the below URL for one-step submission https://juniperpublishers.com/online-submission.php 